\title{
Por um aconselhamento pastoral integral a partir do diálogo entre teologia e demais Ciências humanas
}

\author{
Orientador: Abimar Oliveira de Moraes
}

Doutorando: Aloísio Said Bacelar

Área de Concentração: Teologia Sistemático-Pastoral

Linha de Pesquisa: Fé e Cultura

Projeto de Pesquisa: Questões atuais de Teologia Pastoral

A tese trata do aconselhamento pastoral em perspectiva integral. Dessa forma, apresenta tanto uma breve análise dos traços característicos deste tempo e suas influências sobre os sujeitos humanos, com ênfase nos aspectos que tendem a desestabilizar a experiência existencial, quanto discorre sobre as mais destacadas escolas de aconselhamento pastoral, suas intuições e estratégias de acolhimento das inquietudes e angústias dos que demandam apoio e cuidado. Evidencia a relevância da elaboração de novo modelo de aconselhamento capaz de lidar com a intricada gramatica do sofrimento em nossos dias. Para tanto, destaca a necessidade vital da renovação de esforços que visem superar os dualismos que empobrecem as ações curativas da Igreja Cristã, bem como ultrapassar as barreiras que impedem a enriquecedora troca conversacional entre os diversos saberes e entre as variadas comunidades de fé. A pesquisa aponta ainda para Cristo, maravilhoso conselheiro, como modelo por excelência da atividade e ação dos eclesianos e das eclesianas engajados na promoção do bem-estar integral da família humana. Além disso, reflete sobre a tradição do povo de Deus e a natureza terapêutica da igreja como fontes de inspiração e motivação para a pratica do cuidado interpessoal. Conclui que o aconselhamento pastoral integral, por consequência, dialógico, ecumênico, honestamente aberto para interações francas, respeitosas e enriquecedoras, consiste na expressão mais eficaz e abrangente dessa modalidade de ajuda oferecida pela comunidade Cristã. Este trabalho busca dar contribuição singela para o desenvolvimento deste modelo de aconselhamento.

Palavras-chave: Aconselhamento pastoral. Conselheiros. Sofrimento. 